SJ Quinney College of Law, University of Utah Utah Law Digital Commons

Utah Law Faculty Scholarship

Utah Law Scholarship

$8-2018$

\title{
Evaluation of Circuit Judge Kavanaugh's Opinions Concerning the CAA
}

Arnold W. Reitze Jr.

S.J. Quinney College of Law, University of Utah

Follow this and additional works at: https://dc.law.utah.edu/scholarship

Part of the Environmental Law Commons, Judges Commons, and the Jurisprudence Commons

\section{Recommended Citation}

Reitze, Arnold W. Jr., "Evaluation of Circuit Judge Kavanaugh’s Opinions Concerning the CAA" (2018). Utah Law Faculty Scholarship. 118.

https://dc.law.utah.edu/scholarship/118

This Article is brought to you for free and open access by the Utah Law Scholarship at Utah Law Digital Commons. It has been accepted for inclusion in Utah Law Faculty Scholarship by an authorized administrator of Utah Law Digital Commons. For more information, please contact valeri.craigle@law.utah.edu. 


\section{Evaluation of Circuit Judge Kavanaugh's Opinions Concerning the CAA.}

Arnold W. Reitze, Jr.

S.J. Quinney College of Law

The University of Utah

arnold.reitze@law.utah.edu

August 4, 2018

Nineteen opinions by Circuit Judge Kavanaugh in the D.C. Circuit dealing with the Clean Air Act (CAA) were reviewed. In eleven of the cases, Circuit Judge Kavanaugh wrote the majority opinion. In two cases he wrote a concurring opinion and in six cases he dissented. The cases where Circuit Judge Kavanaugh wrote the majority opinion are: (1) Americans for Clean Energy v. EPA, 864 F.3d 691 (2017); (2) Mexichem Fluor, Inc. v. EPA, 866 F.3d 451(2017); (3) Energy Future Coalition v. EPA, 793 F.3d 141 (2015); (4) EME Homer City Generation, L.P. v. EPA, 795 F.3d 118 (2015); (5) In re Murray Energy v. EPA, 788 F.3d 330 (2015); (6) National Ass'n of Manufacturers v. EPA, 750 F.3d 921 (2014); (7) NRDC v. EPA, 749 F.3d 1055 (2014); (8) American Road \& Transportation Builders Ass'n v. EPA, 705 F.3d 453 (2013); (9) Honeywell International, Inc. v. EPA, 705 F.3d 470 (2013); (10) EME Homer City Generation, L.P. v. EPA, 696 F.3d 7 (2012, rehearing en banc denied Jan. 24, 2013); and (11) American Trucking Ass'ns, Inc. v. EPA, 600 F.3d 624 (2010).

Circuit Judge Kavanaugh's concurring opinions are found in; (1) Utility Air Regulatory Group v. EPA, 744 F.3d 741 (2014); and (2) Center for Biological Diversity v. EPA, 722 F.3d 401 (2013). His dissents are found at: (1) Mexichem Specialty Resins, Inc. v. EPA, 787 F.3d 544 (2015); (2) (2) White Stallion Energy Center, LLC v. EPA, 748 F.3d 1222 (D.C. Cir. 2014); (3)Texas v. EPA, 726 F.3d 180 (2013); (4) Grocery Mfrs. Ass'n v. EPA, 693 F.3d 169 (2012); (5) Sierra Club v. EPA, 536 F.3d 673 (2008), and (6) Coalition for Responsible Regulation v. EPA, 2012 WL 6621785 (Dec. 20, 2012).

\section{Discussion}

Circuit Judge Kavanaugh's opinions in these air pollution cases demonstrate an impressive knowledge of the Clean Air Act (CAA). His opinions are thoroughly researched; his arguments are well organized; and his writing quality is excellent. When deciding a case, Judge Kavanaugh's loadstone is the doctrine of separation of powers as embodied in articles 1,2, and 3 of the U.S. Constitution. This is combined with his focus on the literal language of the statute. He believes a court's assessment of an agency's compliance with statutory limits does not depend on whether the agency's policy is good or whether the agency's intentions are laudatory. Even when that is true, the courts must enforce statutory limits. His view is that a court's job, is not to make the policy choices, but it is to carefully but firmly enforce the statutory boundaries.

In a controversy involving the protection of the environment versus the protection of the powers of Congress, his priority is protecting the legislative branch from efforts by EPA to expand its authority through its interpretation of the CAA. In the eleven CAA cases 
in which Circuit Judge Kavanaugh wrote the majority opinion, ten involved industry petitioners. In six of the cases the petition was denied; in four the court remanded the case back to EPA. His remands are often based on his view that EPA regulations or other actions exceed the Agency's statutory powers.

Judge Kavanaugh's record is impressive. His professional activities are an open book. But the decision to support his nomination will not be based on his qualifications. Chief Circuit Court Judge Merrick Garland had outstanding qualifications when he was nominated but no proceeding were ever held by the Senate. A decision to approve him for a position on the Supreme Court will be based on whether a majority of the Senate will support his conservative views. In terms of the impact on air pollution control, he can be expected to support a stronger Congress and a weaker EPA, which is likely to lead to a relaxation of air pollution control regulation.

\section{Case summaries}

Brief summaries of the nineteen cases follow. Because many cases involve multiple claims for relief only the most important issues that shape the final result are discussed.

\section{Majority opinions}

Americans for Clean Energy v. EPA, 864 F.3d 691 (2017)

Various organizations, companies, and interest groups petitioned for review of the Environmental Protection Agency's (EPA) final rule setting renewable fuel requirements for transportation fuel. Circuit Judge Kavanaugh held: EPA's interpretation of the "inadequate domestic supply" waiver provision for the CAA's renewable fuel program was inconsistent with the CAA. The petition was granted in part, denied in part, vacated in part, and remanded in part.

Mexichem Fluor, Inc. v. EPA, 866 F.3d 451(2017)

Manufacturers of hydrofluorocarbons (HFCs) petitioned for a review of EPA's decision to remove HFCs from list of substitutes for ozone-depleting substances and place it on list of prohibited ozone-depleting substances. The primary issue was whether EPA had statutory authority to issue the 2015 Rule regulating HFCs. EPA issued the rule based on CAA $\S 612$, which requires the replacement of ozone-depleting substances with safe substitutes. However, HFCs are not ozone-depleting substances. Therefore, the court vacated rule 2015 and remanded the case to EPA.

Energy Future Coalition v. EPA, 793 F.3d 141 (2015)

EPA adopted regulations that require vehicle manufacturers to test the emissions from new vehicles using a "test fuel that is "commercially available." Petitioners want EPA to approve E30, which is a fuel that contains about 30\% ethanol, for use as a test fuel. But E30 is not yet "commercially available," as required by EPA's test fuel regulation. Biofuel producers petitioned for review of final action of EPA, arguing that the Agency's test fuel regulation was arbitrary and capricious. The court held EPA's regulation was reasonable and rooted in the CAA, and thus not arbitrary and capricious. The petition was denied. 
EME Homer City Generation, L.P. v. EPA, 795 F.3d 118 (2015)

A group of state and local governments, joined by industry and labor groups, petitioned for review of EPA's Transport Rule, which called for cost-effective allocation of emission reductions among upwind states in order to improve air quality in polluted downwind areas. This provision is known as the good neighbor provision. The D.C. Circuit vacated the rule. The Supreme Court, 134 S.Ct.1584, reversed and remanded the case. On remand, Circuit Judge Kavanaugh, held that: EPA's 2014 sulfur dioxide $\left(\mathrm{SO}_{2}\right)$ emissions budgets for Texas, Alabama, Georgia, and South Carolina that required those States to reduce emissions were invalid; EPA's 2014 ozone-season $\mathrm{NO}_{\mathrm{x}}$ emissions budgets that related to 1997 8-hour ozone national ambient air quality standards (NAAQS) for upwind States that required each of those States to reduce emissions were invalid The case was remanded without vacatur.

In re Murray Energy v. EPA, 788 F.3d 330 (2015)

A coal company and states petitioned for review of EPA's proposed rule restricting carbon dioxide emissions from existing power plants. Circuit Judge Kavanaugh, held that proposed rule was not final agency action subject to judicial review. The petition was denied.

National Ass'n of Manufacturers v. EPA, 750 F.3d 921 (2014)

Manufacturers' association and industry groups petitioned for review of the EPA's lowering of the National Ambient Air Quality Standard (NAAQS) for fine particulate matter from 15.0 $\mu \mathrm{g} / \mathrm{m}^{3}$ to $12.0 \mu \mathrm{g} / \mathrm{m}^{3}$.

Circuit Judge Kavanaugh held that EPA's decision to lower the NAAQS for particulate matter and its decision to eliminate the use of spatial averaging to demonstrate compliance with the NAAQS was not unreasonable. In addition, EPA's addition of a near-road component to the monitoring network for demonstrating NAAQS compliance was not unreasonable.

The petition was denied.

NRDC v. EPA, 749 F.3d 1055 (2014)

Environmental associations petitioned for review of final actions of EPA concerning its rules under the CAA to limit emissions of certain pollutants from cement plants.

Circuit Judge Kavanaugh held that EPA's interpretation of the CAA's "other requirements preserved" provision and its decision to allow consideration of cost-effectiveness as a component of the cost analysis for emissions standards was reasonable; but the Agency exceed its authority in adopting affirmative defense to private civil suits under the CAA.

The court granted the petitions for review with regard to EPA's affirmative defense, and it vacated those portions of the 2013 Rule pertaining to the defense, but it denied the petitions in all other respects. 
American Road \& Transportation Builders Asso. v. EPA, 705 F.3d 453 (2013, rehearing en banc denied April 30, 2013)

This trade organization petitioned for review of an order of EPA to amend two regulations implementing section 209 of the CAA prohibiting states from imposing certain emissionsrelated regulations on nonroad engines and vehicles. ARTBA began bringing those challenges several years after the regulations relating to nonroad engines and vehicles were promulgated. However, the petition for review was dismissed because venue was not proper in the Court of Appeals for the District of Columbia on claim challenging EPA's approval of California's state implementation plan (SIP), and, in addition, the challenge to EPA's regulations was time-barred.

Honeywell International, Inc. v. EPA, 705 F.3d 470 (2013)

EPA administers a cap-and-trade program regulating the production and consumption of hydrochlorofluorocarbons. It incorporated competitors prior hydrochlorofluorocarbon (HCFC) transfers into subsequent baseline allowances which reduced other manufacturers' HCFC market share and allowances under cap-and-trade program. The manufacturers petitioned for judicial review. Because there is an overall cap on HCFC-22 production, this is a zero-sum system: The increased allowances to Arkema and Solvay in turn reduced Honeywell's market share and allowances of HCFC-22. However, the Court in Arkema, Inc. v. EPA concluded that those permanent transfers were valid under the Clean Air Act. Absent en banc review, this decision is circuit precedent. And because Honeywell's other challenges to the 2008 transfers are meritless, the court denied the petitions for review.

EME Homer City Generation, L.P. v. EPA, 696 F.3d 7 (D.C. Cir. 2012, rehearing en banc denied Jan. 24, 2013).

This case involves the "good neighbor" provision of the CAA that requires states to prevent sources within their borders from emitting federally determined "amounts" of pollution that travel across State lines and "contribute significantly" to a downwind State's "nonattainment" of federal air quality standards. In August 2011, to implement the statutory good neighbor requirement, EPA promulgated the rule at issue in this case, the Transport Rule, also known as the Cross-State Air Pollution Rule (CSAPR). The Transport Rule defines emissions reduction responsibilities for 28 upwind States based on those States' contributions to downwind States' air quality problems. The Rule limits emissions from upwind States' coal- and natural gas-fired power plants, among other sources. The Transport Rule targets two of those pollutants, sulfur dioxide $\left(\mathrm{SO}_{2}\right)$ and nitrogen oxides $\left(\mathrm{NO}_{\mathrm{x}}\right)$.

Circuit Judge Kavanaugh held that EPA exceeded its statutory authority under the "good neighbor" provision of the Clean Air Act in implementing the Transport Rule, and EPA could not issue Federal Implementation Plans (FIPs) without giving States an initial opportunity to implement the required emissions reductions through State Implementation Plans (SIPs) or through SIP revisions. The CSAPR was vacated and remanded.

American Trucking Ass'ns, Inc. v. EPA, 600 F.3d 624 (2010) 
The petitioners representing the United States trucking industry petitioned for review of EPA's decision to authorize California's rule limiting emissions from in-use non-road engines, particularly transportation refrigeration units (TRU) powered by diesel engines. Congress has given California the primary role in regulating emissions from in-use nonroad engines. EPA must approve a proposed California regulation unless: (1) EPA finds that California unreasonably determined that its rule is at least as protective of public health and welfare as the relevant federal standards; (2) EPA concludes that California does not need the proposed standard "to meet compelling and extraordinary conditions" in California; or (3) EPA finds that California's standards "are not consistent with" the CAA's requirements that requires EPA to assess whether the California rule prevents other states from deciding to "adopt and enforce" the California rule.

Circuit Judge Kavanaugh held that EPA's conclusion that California's rule was needed was not arbitrary and capricious; the rule did not impose a de facto national rule that precluded other states from declining to follow it; and EPA adequately considered cost of compliance. The petition was denied.

\section{Concurring opinions}

Utility Air Regulatory Group v. EPA, 744 F.3d 741 (2014)

This case involved petitions by a State and industry group challenging final rules issued by EPA regulating particulate matter from fossil-fuel-fired steam generating units. The focus of the petitioners was on the rule's requirements for monitoring and measuring emissions Chief Judge Garland, writing for the majority, upheld the rules by finding they were not arbitrary and capricious. Circuit Judge Kavanaugh concurred with the decision, and his opinion merely made the observation that the exhaustion/finality rule used by the majority should not be considered jurisdictional.

\section{Center for Biological Diversity v. EPA, 722 F.3d 401 (2013)}

In this case, environmental groups petitioned for review of EPA's administrative action, which deferred regulation of "biogenic" carbon dioxide, which includes ethanol, for a period of three years. In support of this so-called Deferral Rule, EPA's Deferral Rule exempts from regulation biogenic carbon dioxide sources that trigger the PSD and Title V permitting programs at Step Two of the Tailoring Rule. The rule accomplishes this by amending the regulatory definition of "greenhouse gases" to exclude biogenic carbon dioxide. The so-called "anyway" sources that obtained PSD and Title V permits during Step One of the Tailoring Rule, however, must still install BACT for their biogenic carbon dioxide emissions. The Deferral Rule has a three-year sunset provision whereas the de minimis doctrine "is used to establish permanent exemptions." Given this concession, the Deferral Rule cannot be sustained under the de minimis doctrine. The one-step-at-a-time doctrine, which EPA does defend, authorizes agencies to promulgate regulations in a piecemeal fashion. However, EPA's invocation of the one-step-at-a-time doctrine was arbitrary and capricious. Therefore, the administrative action was vacated.

Circuit Judge Kavanaugh in his concurring opinion stated there is zero basis in the text of the Clean Air Act for EPA to distinguish biogenic carbon dioxide from other sources of 
carbon dioxide that EPA is required to regulate for purposes of the PSD and Title V permitting programs. statute does not give EPA the authority to distinguish a stationary source's emissions of biogenic carbon dioxide from emissions of other forms of carbon dioxide for purposes of these permitting programs. He stated "I have mixed feelings about this case. That's because I believe, contrary to this Circuit's precedent, that the PSD statute does not cover carbon dioxide, whether biogenic or not." However, he believes the court is bound to apply the precedent that requires EPA is required to regulate carbon dioxide under the PSD and Title V permitting programs. There is no statutory basis for exempting biogenic carbon dioxide.

\section{Dissenting opinions}

Mexichem Speciality Resins, Inc. v. EPA, 787 F.3d 544 (2015)

Manufacturers of polyvinyl chloride challenged EPA's rule limiting emissions of hazardous air pollutants. The court upheld EPA's rule including its rule requiring all releases of pollutants by pressure relief devices to meet the rule's process vent emissions limits. The rule was held not to be arbitrary and capricious, and the petition was denied.

Circuit Judge Kavenaugh dissented in part. EPA's PCV rule imposed limits on emissions of hazardous air pollutants. But EPA later concluded that one category of those limits-the socalled wastewater limits on hazardous air pollutants that may be dissolved in wastewater-was based on bad data. EPA therefore said it was reconsidering the wastewater limits, and it would complete the reconsideration process in 2016.

Petitioners, contended that EPA's flawed wastewater limits should be stayed under the Administrative Procedure Act provision authorizing stays pending judicial review. Judge Kavanaugh believes the petitioners are correct. They have demonstrated a likelihood of success on the merits; they have shown irreparable harm; and they have precedent on their side. EPA did not oppose a stay in this case. Given the circumstances, as well as precedent, Judge Kavanaugh supported a stay of the wastewater limits pending judicial review, and he dissented from the majority opinion's decision not to stay EPA's wastewater limits.

White Stallion Energy Center, LLC v. EPA, 748 F.3d 1222 (D.C. Cir. 2014)

This case involves state, industry, labor and environmental entities that petitioned for review of EPA's final rule regulating hazardous air pollutants (HAPs) emitted from electric utility steam generating units (EGUs). The majority opinion held that EPA reasonably relied upon CAA criteria for delisting pollutants in determining necessity of regulating EGU emissions; EPA reasonably concluded that it was not required to consider costs in determining whether to regulation EGU emissions; and EPA reasonably concluded that it could regulate all HAP emissions from EGUs. The court also determined that EPA findings on health effects of mercury exposure supported regulating these EGU emissions, and EPA reasonably relied upon chromium emissions data in assessing risks from non-mercury EGU emissions. The petition was denied. 
Circuit Judge Kavanaugh filed an opinion concurring in part and dissenting in part. Under the CAA's $\S 112(\mathrm{n})$ coal- and oil-fired electric utility steam generating units are held to a different standard for hazardous air pollution emissions with EPA being charged with making "appropriate and necessary" regulations. The statute is not clear concerning whether costs must be considered. EPA did not consider costs, which are huge. Circuit Judge Kavanaugh disagreed with the majority that upheld EPA's exclusion of costs He believes that "appropriate" mandates the consideration of costs. He also believes that competitors of regulated companies should be considered to be within the zone of interests needed to have standing under the Administrative Procedure Act.

Texas v. EPA, 726 F.3d 180 (2013)

The States of Texas and Wyoming and industry groups petitioned for review of five EPA rules designed to ensure that permitting authority existed to issue greenhouse gas permits under the CAA. Circuit Judge Rogers held that the states and industry groups failed to establish the challenged rules caused them injury in fact, as required to establish standing. Thus, the petitions were dismissed.

Circuit Judge Kavanaugh dissented. EPA's GHG emissions regulations require states to revise the portions of their SIPs incorporating the PSD program, which requires construction permits for large construction projects. EPA set deadlines for states to update their SIPs, which Texas and Wyoming did not meet. EPA then imposed FIPs, for Texas and Wyoming. Petitioners challenged EPA's action. Judge Kavanaugh looked at the relevant EPA regulations, which gives States three years to revise their SIPs whenever new pollutants, like greenhouse gases were regulated under EPA's PSD regulations. EPA also relied on an alternative ground in imposing a FIP on Texas. EPA retroactively disapproved Texas's pre-existing SIP because, according to EPA, the SIP was flawed when EPA approved it 18 years earlier. But neither the Act nor EPA regulations require either an automatic updating SIP or assurances that the state will update its plan. Therefore, Texas's SIP was not flawed when EPA approved it 18 years earlier, and it cannot be retroactively disapproved on that basis. He would vacate the relevant EPA orders.

Grocery Mfrs. Ass'n v. EPA, 693 F.3d 169 (2012)

Trade associations comprised of engine manufacturers, petroleum suppliers, and food producers petitioned for review of EPA's final actions that granted partial waivers under the CAA approving introduction into commerce of E15, which is a blend of gasoline and $15 \%$ ethanol, for use in select motor vehicles and engines. Chief Judge Sentelle held that the various petitioners lacked standing, and the petition was denied.

Circuit Judge Kavenaugh dissented. In order to issue the waiver under the statute, EPA had to find that E15 would not cause any car models made after 1974 to fail to meet emissions standards. EPA found that E15 could cause emissions failures in some cars made after 1974 (namely, in cars made between 1975 and 2000). Nonetheless, for the first time, EPA granted what it termed a "partial waiver," meaning that the waiver allowed E15 use only in cars made after 2000.

Two important American industries could be negatively affected by EPA's allegedly illegal 
E15 waiver, but the majority opinion rejected the petition based on a lack of standing. Judge Tatel and Judge Kavanaugh agree that the food group had standing. But the majority opinion found that the food group was not an aggrieved party (that is, it did not have prudential standing) for purposes of the Administrative Procedure Act. And the majority opinion concluded that the petroleum group's injury is not caused by EPA's E15 waiver decision, therefore it does not have Article III standing. Judge Kavanaugh believes both groups had standing, and he provided a detailed brief on the law of standing. However, on the merits he concludes that in order to issue the waiver under the statute, EPA had to find that E15 would not cause any car models made after 1974 to fail to meet emissions standards. EPA found that E15 could cause emissions failures in some cars made after 1974 (namely, in cars made between 1975 and 2000). Nonetheless, EPA still granted a "partial waiver," meaning that the waiver allowed E15 use only in cars made after 2000. Judge Kavanaugh believes that "In granting the E15 partial waiver, EPA ran roughshod over the relevant statutory limits." He stated, "EPA's disregard of the statutory text is open and notorious-and not much more needs to be said."

Sierra Club v. EPA, 536 F.3d 673 (2008),

Environmental organization filed a Petition for Review concerning EPA's final order that prevented state and local authorities from supplementing federal monitoring requirements under the CAA. Circuit Judge Griffith held that the rule contravened a statutory directive that stationary-source emission permits include adequate monitoring requirements, and the preexisting monitoring rules were consistent with statute. The petition was granted in part and denied in part.

Circuit Judge Kavanaugh dissented claiming the relevant statutory language supports the rule. The CAA $\S 504(\mathrm{c})$ grants EPA the authority to determine whether state and local permitting authorities can impose additional monitoring requirements that "conform to any applicable regulation under subsection (b) of this section." In turn, subsection (b) says EPA "may by rule prescribe procedures and methods for determining compliance and for monitoring and analysis of pollutants regulated under this chapter...." EPA has decided state and local permitting authorities may not add new periodic monitoring requirements when issuing permits. EPA determined that the permitting process is not the time and place for state and local permitting authorities to add new periodic monitoring requirements. Rather, if changes are to be made to the underlying monitoring requirements, they should occur during the process for formulating and revising SIP, NSPS, NESHAP, and other applicable requirements. Therefore, Judge Kavanaugh would reject petitioners' primary statutory argument and deny the petition in whole.

Coalition for Responsible Regulation v. EPA, 2012 WL 6621785 (Dec. 20, 2012)

A central question in this case was how to construe the term "air pollutant" for purposes of a statutory permitting requirement. Does the term "air pollutant" cover not just the six criteria pollutants, but also greenhouse gases such as carbon dioxide, which contribute to global warming? Under the broader interpretation of "air pollutant" that encompasses greenhouse gases, a far greater number of facilities would fall within the Prevention of Significant Deterioration program and have to obtain pre-construction permits. That in turn would impose significantly higher costs on businesses and individuals that are 
building new commercial or residential property. Judge Kavanaugh believed EPA exceeded its statutory authority, and he disagreed with the panel opinion's contrary conclusion.

He believes Massachusetts v. EPA, 549 U.S. 497 (2007), is not controlling and the text and context of the Prevention of Significant Deterioration program as a whole, demonstrates the term "air pollutant" refers to the six criteria (NAAQS) air pollutants. EPA has long held the PSD program regulates all pollutants regulated by the CAA and not just the six criteria pollutants. This creates problems because the threshold for PSD applicability, if applied to GHGs would trigger a dramatically higher number of facilities that would be subject to the need for pre-construction permits. For this reason, EPA re-wrote the very specific 250-ton trigger in the permitting requirement of the statute in its Tailoring Rule to raise the trigger for GHG emissions from 250 tons to 100,000 tons. Judge Kavanaugh held that this rule if upheld would allow agencies to adopt absurd or otherwise unreasonable interpretations of statutory provisions and then edit other statutory provisions to mitigate the unreasonableness. Allowing agencies to exercise that kind of statutory re-writing authority could significantly enhance the Executive Branch's power at the expense of Congress's and thereby alter the relative balance of powers in the administrative process.

He makes a compelling argument that the PSD program is limited to NAAQS pollutants, but once a facility is subject to PSD section 7475(a)(4) imposes requirements on other pollutants regulated by the Act, including GHGs, that include the need to meet BACT. In Massachusetts v. EPA, the Supreme Court explicitly relied on the fact that the Clean Air Act's definition of 'air pollutant' "did not produce "extreme" consequences in the context of motor vehicle emissions. But, when applied to the PSD program EPA's definition of air pollutant produces extreme consequences. He concludes EPA chose an admittedly absurd reading over a perfectly natural reading of the relevant statutory text. An agency cannot do that. 
